\title{
Impact of E-government Development on the Level of Corruption: Measuring the Effects of Related Indices in Time and Dimensions
}

\author{
Renáta Máchová, Jolana Volejníková1, Martin Lněnička²
}

\begin{abstract}
E-government is recognized as a tool for improving transparency and openness in the public sector and for combatting corruption. Understanding the relationship between e-government development and the level of corruption would allow for a more effective leveraging of related projects in anti-corruption efforts. This paper examines the impact of e-government development on the level of corruption in the context of economic perspective. In contrast to previous studies, this empirical relationship is measured across sub-indices (dimensions) of related indices between 2002 and 2016 . The results show that higher levels of e-government development are related to lower levels of corruption. The three most important dimensions found are the environment sub-index, which assesses the extent to which a country's market conditions and regulatory framework support entrepreneurship, innovation, and ICT development; the usage sub-index, which assesses the level of ICT adoption by a society's main stakeholders; and the telecommunication infrastructure sub-index measuring a country's ICT infrastructure capacity. Following these findings, certain ways of influencing of the level of corruption by a stimulation of concrete e-government development dimensions can be drawn. This is important especially in the time of a financial crisis and its consequences, which are also discussed in this paper.
\end{abstract}

Key words: correlation analysis, corruption, dimensions, e-government development, indices, regression models

JEL Classification: C43, D73, H11, L86, O38

Received: 23 October 2017/Accepted: 8 March 2018 / Sent for Publication: 4 June 2018

\footnotetext{
${ }^{1}$ Faculty of Economics and Administration, University of Pardubice, Studentská 84, 53210 Pardubice, Czech Republic, renata.machova@upce.cz, jolana.volejnikova@upce.cz.

${ }^{2}$ Business Academy and Secondary School of Tourism, T. G. Masaryka 1000, 56536 Choceň, Czech Republic, martin.Inenicka@gmail.com.
}

(c) 2018 by the authors; licensee Review of Economic Perspectives / Národohospodářský obzor, Masaryk University, Faculty of Economics and Administration, Brno, Czech Republic. This article is an open access article distributed under the terms and conditions of the Creative Commons Attribution 3.0 license, Attribution - Non Commercial - No Derivatives. 


\section{Introduction}

Technology is continuously changing how governments operate, interact, and serve the public (Bertot et al., 2012; Elbahnasawy, 2014; Kim, 2014; Shim and Eom, 2008; United Nations, 2016). In this regard, countries around the world have utilized Information and Communication Technologies (ICT) to efficiently provide information and services to the public (Bertot et al., 2012; Mistry and Jalal, 2012; Ramaswamy and Selian, 2009). ICT are seen as a cost-effective and convenient way of reducing unnecessary interventions by public officials that may lead to the abuse of power, helping to monitor their behaviour and actions, promoting openness and transparently providing information and services to the public (Andersen, 2009; Bertot et al., 2010; Kim et al., 2009; Linhartová, 2017; Mistry and Jalal, 2012; Shim and Eom, 2009). However, the effectiveness of using ICT as a means of fighting corruption is affected by various factors that need to be explored and their effects measured (Elbahnasawy, 2014; Kim, 2014; Shim and Eom, 2008).

Corruption is listed as one of the most prevalent and persistent challenges in enhancement of the economic growth and the improvement of the quality of life of citizens across the globe (Bertot et al., 2012; Bussell, 2011; Linhartová, 2017; Mauro, 1997; Mistry and Jalal, 2012). Since corruption is a complex term, it has various connotations and denotations. For example, Jain (2001) defines corruption as "acts in which the power of public officials is used for personal gains in a manner that contravenes the rules of the game"; and it has been classified as grand, bureaucratic, and legislative. Most of the efforts of the past decades to address corruption typically began with an analysis of the underlying causes or enabling factors of corruption (Bardhan, 1997; Escresa and Picci, 2017; Kim, 2014; Mistry and Jalal, 2012; Mo, 2001). Negative effects on development of Gross Domestic Product (GDP), unemployment rate or credibility of the country discouraging foreign investors have been presented as results of corruption (Bardhan, 1997; Jain, 2001; Knězáčková and Linhartová, 2013; Mistry and Jalal, 2012; Mo, 2001).

The evolution of the Internet has created the underlying infrastructure for e-government, both in information and service delivery (Ojha et al., 2008). E-government can be referred to as "the use and application of ICT in public sector to streamline and integrate workflows and processes, to effectively manage data and information, enhance public service delivery, as well as expand communication channels for engagement and empowerment of people," (United Nations, 2016). The level of e-government development indicates the quality of a country's technological and telecommunication infrastructure and the ability of its citizens, businesses and governments to adopt, use and benefit from modern technologies in the given time period (Máchová and Lněnička, 2015). As governments at different levels and all around the world are increasingly using the Internet to improve their services, it has become important to focus on e-government development and affecting factors (Siau and Long, 2006). As a result, e-government has risen to prominence as one of the tools to fight corruption and to promote economic development (Elbahnasawy, 2014; Kim, 2014; Linhartová, 2017).

In 2008, Ojha et al. published a paper in which they argued that neutral impact assessment reports continue to expose cases where corruption persists even after the introduction of e-government. Some of the new studies indicate that e-government has a positive impact on the reduction of corruption in government (Kim, 2014; Knězáčková and Lin- 
hartová, 2013; Lupu and Lazar, 2015; Mistry and Jalal, 2012; Prasad and Shivarajan, 2015; Srivastava et al., 2016). However, such approaches come with certain shortcomings. For example, as stated by Grönlund and Flygare (2011), different indices should be tested to ensure that the effects of e-government are robust across different indices and their rankings. Most of related empirical studies ignore these different indices, although they are commonly used and sometimes also are more suitable as they consist of various ICT dimensions. Furthermore, for changes to be discernible there is a need for a long time span in order to observe any greater changes in corruption levels within countries (within-country variation) (Andersen, 2009; Bussell, 2011; Grönlund and Flygare, 2011; Lupu and Lazar, 2015; Mistry and Jalal, 2012; Shim and Eom, 2009). More precisely, as stated by Kim (2014), a cross-time study would also give a better picture of whether or not e-government is an efficient tool of reducing corruption in government. Finally, an adequate data sample is required to detect the difference between developed and developing countries (Andersen, 2009; Escresa and Picci, 2017; Grönlund and Flygare, 2011; Mistry and Jalal, 2012; Shim and Eom, 2009).

To overcome these shortcomings, this paper uses established indices to measure the relationship between e-government development and the level of corruption. All of the indices have been examined from the year they were first introduced and on. Finally, the dimensions of the indices have been studied to get a deeper insight into this relationship. The use of decomposed sub-indices (dimensions) rather than one aggregate index of egovernment development allows for a more accurate evaluation as it shows the effects of the different e-government dimensions on the level of corruption. The following research questions have been applied to reach this study's objectives:

1. Is there any relationship between corruption and e-government development on the national level?

2. Is there any progress in the trend of this relationship in the examined period?

3. Do e-government development indices explain the level of corruption consistently, i.e., does a good score on an e-government development index predict a good score on a corruption index consistently over time?

4. What e-government development indices or dimensions have the strongest link to the level of corruption, i.e. what indices are the best predictors of reduction in corruption?

The rest of the paper is organized as follows. In the theoretical background section, the theoretical relationship between the research topics is investigated. In the methodology and methods section, the research methodology is described together with data sources, measures and related indices. The empirical findings are reported and discussed in the following section. Subsequently, the limitations of the study are outlined. The last section concludes the paper and gives a summary.

\section{Literature Review and Background}

\section{Corruption and Economic Development}

The question of whether corruption can affect the economic level of countries or their economic growth is still generating controversy among researchers. On the other hand, if there is adequate legislation and enforcement, the argument about corruption as the 
"grease" or "speed money" of economy is unacceptable (Bardhan, 1997; Jain, 2001; Mauro, 1997). The economic transition from poor to rich strongly reduces corruption, while periods of high inflation increase it. This way, the more economically developed countries are exposed to the temptation of state power abuse less than the poor economies. However, assuming the citizens of rich countries are more educated, their transactions are faster and more transparent than in traditional societies where the boundaries between public and private are less obvious.

Empirical studies dealing with this issue provide quantified consequences of corrupt activities on the economy. These studies explore the correlation between corruption and indicators of economic performance or growth and the overall economic level of the country, i.e. the changes in the dynamics of GDP growth or in the level of GDP per capita. According to Leite and Weidmann (1999), Mauro (1995), Mauro (1997) or Tanzi and Davoodi (2001), the corruption has a quantifiable negative impact on the economic performance and growth, where a decrease in corruption by $1 \%$ on a scale of 0 10 leads to a decrease in GDP per capita by $2 \%$. Mauro (1995) analyses a set of data consisting of subjective indices of corruption and various factors for a cross section of countries. The results show that corruption decreases economic growth. In 1997, Mauro expanded this analysis and presented new evidence on the relationship between corruption and the composition of government expenditure. These findings have been confirmed and further expanded by studies of Brunetti et al. (1998), Gyimah-Brempong (2002) or Knack and Keefer (1995).

There are also many transmission channels through which corruption can reduce economic growth. Mo (2001) in his study applies Ordinary Least Squares (OLS) estimations and finds that a $1 \%$ increase in the corruption level reduces the growth rate by about $0.72 \%$. The most important channel is political instability, which accounts for about $53 \%$ of the total effect. Mistry and Jalal (2012) mention that the drivers of corruption, such as monopoly of power, discretion or the lack of accountability are mitigated by the existence of strong legal systems and better equipped organizations. Current research provides an argument that efforts to challenge corruption are especially important in the developing world (Ahmad and Brookins, 2007; Mistry and Jalal, 2012; Kim, 2014). The literature further introduces yet another view on this topic. For example, Escresa and Picci (2017) propose a new measure of corruption, the Public Administration Corruption Index (PACI) reflecting the propensity of public officials to accept bribes from foreign firms (cross-border corruption cases). Finally, empirical papers studying the determinants of corruption usually rely on the variation in corruption levels across countries (between-country variation) (Andersen, 2009).

\section{E-government and its Anti-Corruption Effects}

Prior to the use of e-government as an anti-corruption tool, administrative reforms were considered as an approach to reform public sector organizations. Other reforms include strategic planning, public sector downsizing, better monitoring of government expenditure, or the establishment of formalized rules (Armantier and Boly, 2011; Jain, 2001; Olken, 2009). However, with the rise of widely available and cost-effective ICT infrastructures and services, e-government has become a major topic of interest to practitioners and researchers (Kim et al., 2009; Kim, 2014; Linhartová, 2017; Lupu and Lazar, 2015; Mistry and Jalal, 2012; Shim and Eom, 2008). 
Among the most important factors influencing the growth of e-government are income levels, development status, strength of organizations and the commitment of the government to promote the use of e-government (Christou and Simpson, 2009; Pérez et al., 2005; Siau and Long, 2006; West, 2004). The level of e-government development is determined by the economic growth of the country (Kim, 2007; Mistry and Jalal, 2012; Siau and Long, 2006). Transparency is promoted as one of the most important visions against corruption (Lindstedt and Naurin, 2010). Bertot et al. (2010) deal with the potential impacts of e-government and social media on cultural attitudes towards transparency. In a follow-up article, they examined the ways in which governments build social media and ICT into e-government transparency initiatives to facilitate a collaboration between governments and other stakeholders (Bertot et al., 2012). Mistry and Jalal (2012) also stated that e-government can improve the transparency of the bureaucratic process and, therefore, promote accountability.

Ojha et al. (2008) linked together a few theoretical frameworks that are relevant to corruption studies and reviewed the mechanisms by which e-government reduces or eliminates corruption. As stated by Hopper et al. (2009), electronic delivery of services can reduce corruption by reducing interactions with officials, speeding up decisions, and minimizing human errors. Therefore, the mechanisms through which e-government should work on reducing corruption lie in reducing contacts between corrupt officials and citizens (Andersen and Rand, 2006). The initial network surrounding ICT (particularly e-government) and corruption that theorized the role of basic national organizations and stakeholder service systems into mechanisms through which e-government affects corruption was proposed by Srivastava et al. (2016). Ramaswamy and Selian (2009) focused on the post-communist transitioning countries and proposed a two-stage framework to leverage e-government to combat public sector corruption by using new technologies in the form of e-government systems.

Contrary to these approaches, Kim et al. (2009) have pointed out that there are doubts about whether ICT can in reality effectively reduce corruption or whether it has no measurable effect. Prasad and Shivarajan (2015) reported that there is no clear understanding of the process through which computer-mediated mechanisms reduce corruption. E-government and especially e-government projects may also provide new corruption opportunities. Although governments worldwide are trying to reduce corruption by introducing various frameworks, strategies and action plans, the successful implementation and deployment of these e-government systems vary. For instance, Aladwani (2016) discussed the potential role of corruption in shaping of the failure of e-government projects. For this purpose, the author suggested a theoretical framework depicting the likely influences of corruption on e-government project failure. What should also be noted here is that unsuccessful projects as well as projects not finished on time or within budget may affect the public's perception of e-government development. Nevertheless, none of the existing e-government development indices explicitly measure this effect.

\section{Impact of E-government Development on the Level of Corruption}

The relationship between e-government and corruption on the country/national level has been addressed by the following studies. Andersen and Rand (2006) examined a crosssection of countries and concluded that well-designed ICT policies are likely to be effective in the fight against corruption. Andersen (2009) found that the application of e- 
government can effectively control the tendency of government to corruption. The control of corruption intentions can further improve the adoption of e-government innovations. The findings of Kim (2014) indicated that e-government could be an effective tool to curb corruption in government, despite the fact that the rule of law is the most powerful predictor of anti-corruption and a fundamental precondition for a clean government.

According to Bussell (2011), the level of pre-existing corruption in a country is a robust predictor of e-government outcomes. More corrupt governments hinder the implementation of high-quality public service reforms using ICT. Shim and Eom (2008) stated that both e-government and traditional anti-corruption factors have a positive impact on reducing corruption. In a follow-up article, Shim and Eom (2009) argued that ICT has the potential to reduce any unnecessary human intervention in government work processes, which reduces the need to monitor corrupt behaviour. Finally, e-government also reduces human asset specificity but is redeployed using e-government (Prasad and Shivarajan, 2015). The findings of Elbahnasawy (2014) revealed that e-government is a powerful tool for reducing corruption via telecommunication infrastructure and the scope and quality of online services, which is strengthened by greater Internet adoption. Shahkooh et al. (2008) applied a correlation analysis and clustering to show the relation between a country's corruption and e-government development levels. The models of Mistry and Jalal (2012) suggested that a 1\% increase in the E-government Development Index (EGDI) could result in a $1.17 \%$ decrease in corruption. Focusing on the practical side of this issue, Kim et al. (2009) have developed an anti-corruption system called OPEN (Online Procedures Enhancement for civil application) to show how an egovernment system for anti-corruption in a local government may evolve to become a prototype of a national system to be used for the same purpose.

Together, these studies indicate that it is crucial to support an easier access to information and public services using various e-government systems. More precisely, a high level of e-government development should result in the prevention of public officials' corrupt behaviour by publicly releasing information online about governmental policy making and service delivery processes (Kim et al., 2009; Kim, 2014; Mistry and Jalal, 2012; Prasad and Shivarajan, 2015; Shim and Eom, 2008; Shim and Eom, 2009).

Nowadays, the open government movement is a key part of e-government development and, as identified by Attard et al. (2015), corruption is the major problem that has triggered open government data initiatives. The main goals of these efforts are enhancing collaboration, efficiency, innovation, participation, transparency, and fighting corruption. The most common approaches include open data portals at various levels in order to make these data available for reuse, providing advanced tools for data discovery, extraction, transformation and publication, and to promote new services that use open data (Attard et al., 2015; Evans and Campos, 2013; Máchová and Lněnička, 2016a). The availability and use of these approaches, however, vary around the world; not only in terms of the number of datasets released and how they are presented and organized, but also in terms of the tools provided to increase the usage of these data (Máchová and Lněnička, 2017). On the other hand, the public is allowed to analyse these data or comment on related issues through various communication channels to boost transparency of governmental actions. Therefore, this issue requires further research in the context of e-government development and how these trends of open government may affect it. 


\section{Methodology and Methods}

To achieve the paper's objectives, well-established and internationally recognized measures of corruption and e-government development are examined. While it is important to obtain an adequate data sample, the global indices are applied. Another selection criterion has been the longevity of the index because effects of anti-corruption efforts and e-government projects are likely to take some time to show.

\section{Measures of Corruption}

The majority of data useful for the corruption analysis could not be obtained in the form of freely available statistics (hard data) and thus the indicators measuring the level of corruption are usually based on soft data gained in opinion polls. Standard methods of measuring corruption generally utilize conventional qualitative sociological methods. These qualitative assertions are then quantified and converted into indices that allow international or inter-annual comparisons. Most of them are unique because their construction was conducted in order to capture and analyse a specific purpose or phenomenon. The data are obtained on the basis of specific surveys conducted by various public organizations. These are represented by composite indices, which are based on the comprehensive and robust methodologies. Wei (2001) argues that there are four types of "corruption ratings" (measures): corruption ratings based on expert opinions, surveys of citizens or businesses, a poll of polls (composite indices), and, finally, corruption ratings based on more objective and harder data. In addition, it is necessary to keep in mind that all these corruption indicators primarily measure the perception of corruption rather than objective and precise quantitative extent of corruption.

The dependent variable measures the level of corruption. In this study, two global composite indices are used. The World Bank's Corruption Control Index (CCI) is one of the six broad dimensions of governance for 215 countries since 1996. It captures perceptions of the extent to which public power is exercised for private gain, including both petty and grand forms of corruption, as well as capture of the state by elites and private interests. The CCI considers values between -2.5 (weak) and 2.5 (strong) governance performance. It is based on a large number of individual data sources, which are then aggregated into one measure. This means that the aggregate measure is a weighted average of the underlying individual data sources, with weights reflecting the precision of each of the underlying data sources. According to Andersen (2009), the aggregate CCI is presumably more informative than any other individual data source.

Transparency International has been publishing the Corruption Perceptions Index (CPI) since 1995. It currently covers perceptions of public sector corruption in 168 countries on a scale from 0 (highly corrupt) to 100 (very clean). Until 2012, the scale ranged from 0 to 10 . Countries' scores can be helped with open government where the public can hold leaders to account, while a poor score is a sign of a prevalent bribery, lack of punishment for corruption or public organizations that do not respond to citizens' needs (Transparency International, 2016). The validity of the CPI has been tested by several researchers and a review of these studies can be found in the study by Shim and Eom (2008). The CCI and the CPI are thus used as dependent variables in this paper. 


\section{Measures of E-government Development}

The key explanatory variable in this study is a measure of e-government development. From a global perspective, established indices include the United Nations' (UN) EGDI, the World Economic Forum's (WEF) Networked Readiness Index (NRI) and the International Telecommunication Union's (ITU) ICT Development Index (IDI). A comprehensive classification of these indices can be found in Máchová and Lněnička (2015). For this study's aims, the EGDI, the IDI, and the NRI are used. A brief description of their structure and dimensions is in Table 1. Since the EGDI is only published every two years, the changes between 2002 and 2016 have been examined on the two-year period basis. This methodological approach is in line with Andersen (2009) as it is only appropriate to study whether changes in e-government can explain changes in corruption over the time-span in which e-government has actually been in operation.

Table 1 Description of selected e-government development indices

\begin{tabular}{ccccc} 
Name & Publisher & $\begin{array}{c}\text { Years covered } \\
\text { (no. of reports) }\end{array}$ & $\begin{array}{c}\text { Countries covered } \\
\text { (first-last report) }\end{array}$ & Dimensions (sub-indices) \\
\hline EGDI & UN & $2001-2016(9)$ & $190-193$ & $\begin{array}{c}\text { Online service, human capital, } \\
\text { telecommunication infrastructure }\end{array}$ \\
IDI & ITU & $2002-2016(10)$ & $154-175$ & $\begin{array}{c}\text { Access, use, skills } \\
\text { NRI }\end{array}$ \\
WEF & $2002-2016(15)$ & $82-139$ & $\begin{array}{c}\text { Environment, readiness, usage, } \\
\text { impact }\end{array}$ \\
\hline
\end{tabular}

Source: UN, ITU, WEF.

The EGDI, which assesses e-government development at the national level, is a composite measure based on the weighted average of three normalized sub-indices: Online Service Index (OSI), Telecommunication Infrastructure Index (TII) and Human Capital Index (HCI). It measures the adequacy of telecommunication infrastructure, the ability of human resources to promote and use ICT, and the availability of online services and content (United Nations, 2016).

The first sub-index of the IDI measures the availability of ICT infrastructure and access, the second one is focused on the level of ICT use, and the last one captures the capability to use ICT effectively, derived from relevant skills. The choice of indicators included in these sub-indices reflects the corresponding stage of evolution to the information society. The indicators in each sub-index can therefore change over time to reflect technological developments related to ICT and improvements in the availability and quality of data (International Telecommunication Union, 2016).

The NRI has evolved over time and currently assesses the state of networked readiness over these dimensions: (1) environment sub-index, which measures the overall environment for technology use and creation (political, regulatory, business, and innovation); (2) readiness sub-index, which captures the networked readiness in terms of ICT infrastructure, affordability, and skills; (3) usage sub-index, which measures technology adoption and usage by these groups of stakeholders - government, the private sector, and private individuals; and (4) impact sub-index, which captures the economic and social impact of the new technologies (World Economic Forum, 2016). 


\section{Measure of Economic Development}

As discussed earlier, the level of economic development is significantly linked to corruption reduction (Bertot et al., 2012; Bussell, 2011; Elbahnasawy, 2014; Kim, 2007; Kim, 2014; Mistry and Jalal, 2012; Tanzi and Davoodi, 2001). As a result, it can be argued that changes in corruption may only be caused by the economic development of the country and ICT may not be associated with corruption (Mistry and Jalal, 2012). Therefore, in this paper economic development is controlled by including the natural logarithm of GDP per capita of the countries. The data are from the World Bank's database named the World Development Indicators.

\section{Empirical Methodology and Data Analysis}

The relationship is tested by proposing empirical models that examine how changes in e-government development in selected countries are linked to changes in their levels of corruption. The unit of analysis is the country and the period covered is 2002-2016. For this purpose, OLS regression models and correlation analysis are used. Correlations between defined variables are measured by the value of the Pearson's correlation coefficient. According to Nardo et al. (2008), several correlation measures (measures of association) can be used to validate the conformity of the rank methods for the indices. In this study, Spearman's and Kendall's rank correlation coefficients are used. Contrary to Spearman's coefficient, Kendall's coefficient is not affected by how far from each other the ranks are but only by whether the ranks between cases are equal or not (Nardo et al., 2008).

For the purpose of exploring the relationship between corruption and e-government development, the OLS regression equation has previously been validated for use by Andersen and Rand (2006); Knězáčková and Linhartová (2013), Linhartová (2017), Lupu and Lazar (2015), Mistry and Jalal (2012) and Srivastava et al. (2016). In contrast to these studies, this paper explores this relationship on a more detailed level of decomposed e-government development indices, and the equation has been changed and applied in the multidimensional context. It is defined as illustrated in (1):

$$
\text { corruption_index }=\alpha+\beta * \text { egovernment_index }+\gamma * \text { country _development }+\varepsilon
$$

where the dependent variable corruption_index is represented by the CPI and CCI in selected years, the independent variable egovernment_index corresponds with dimensions of decomposed e-government development indices, and country_development is the natural log of GDP. The parameter $\alpha$ determines the distance of intersection of the regression line with the $y$-axis (the value of the regression function for $\mathrm{x}=0$ ). The parameters $\beta$ and $\gamma$ are called the regression coefficients and show the variation of the dependent variable value when the value of the independent variable changes. The symbol $\varepsilon$ is the residual variance, which is a graphical representation of the distance of points from the regression line.

In this paper, the OLS regression methodology with robust standard errors is employed. These Eicker-Huber-White standard errors are intended to control for the possible presence of heteroscedasticity in the sample. White test is then a statistical test that establishes whether the variance of the errors in a regression model is constant (White, 1980). The analysis is performed on a sample of countries regardless of their geographic loca- 
tion or political regime. Data collection has been carried out through open data sources. All calculations and graphics are done in Statistica 10 and Microsoft Excel 2010.

\section{Results and Discussion}

Firstly, relevant statistical indicators for the indices are presented in Table 2. In the case of mean value that has been calculated as a simple average, an increase in e-government development through the years can be observed. This means that the impact of ICT on citizens' everyday life within the public sector is constantly increasing worldwide. The level of corruption is stable worldwide or the score slightly decreases. This implies that there are some factors helping with the reduction of corruption.

The higher mean compared to the median indicates that the distribution of values for all indices is skewed to the left, i.e. there are more countries with lower values than higher ones. However, these results can be slightly affected by changes in the index's construction and calculation methodology, especially in the case of the CPI and IDI. Moreover, as the number of countries covered increases every year and mostly only includes developing countries, this fact may also influence the summary statistics. The Kolmogorov-Smirnov test did not indicate a departure from normality. White's test for heteroscedasticity supports constant variance.

Secondly, the relationship between the selected indices in different time periods is examined. Here, the null hypothesis says that the compared variables are not in a correlative relationship. Verification of this hypothesis is based on the subsequent comparison of the level of significance with a p-value. The correlations between the indices are calculated in order to see how strong the linear dependence is. Fourteen years' worth of indices has been evaluated and the correlations between individual years have been calculated. As results indicated, the two corruption indices are strongly correlated. This means that 0.987 as mean value is an almost perfect correlation which is also stable over the years, i.e. 2002 (0.969), 2004 (0.983), 2006 (0.984), 2008 (0.990), 2010 (0.992), 2012 (0.995), 2014 (0.994), 2016 (0.991).

In Figure 1, the progress of Pearson's correlation coefficients for the indices between examined years can be observed on the significance level 0.05 , giving a value between +1 and -1 , where 1 is total positive correlation, 0 is no correlation, and -1 is total negative correlation. The correlation relationship between the variables from examined years has been found positive. This led to the rejection of the null hypothesis. As mentioned above, high values of e-government development index indicate a higher quality of the country's technological and telecommunication infrastructure and the ability of its citizens, businesses and governments to adopt, use and benefit from modern technologies. Higher values of a corruption index indicate less corruption in the country, i.e. the country is perceived to be very clean with a strong governance performance and a stable political and economic situation. It may be suggested that there is a relationship between the level of corruption and e-government development as represented by the indices in the compared countries. The NRI also has a stronger relationship with both the CPI and CCI than other indices. The results thus suggest that the NRI is a better predictor of the level of corruption than the EGDI or IDI. 
Table 2 Summary statistics of the indices included in the study

\begin{tabular}{|c|c|c|c|c|c|c|c|c|c|}
\hline Index & Measure & 2002 & 2004 & 2006 & 2008 & 2010 & 2012 & 2014 & 2016 \\
\hline \multirow[t]{6}{*}{$\mathrm{CCl}$} & Number of cases & 197 & 206 & 206 & 207 & 211 & 210 & 210 & 209 \\
\hline & Mean (value) & -0.020 & 0.001 & 0.001 & 0.001 & 0.001 & 0.001 & 0.001 & 0.001 \\
\hline & Mean ( $\%$ change) & - & 0.4 & 0 & 0 & 0 & 0 & 0 & 0 \\
\hline & Std. dev. (value) & 1.005 & 0.998 & 0.998 & 0.998 & 0.998 & 0.998 & 0.998 & 0.998 \\
\hline & Std. dev. (\% change) & - & -0.1 & 0 & 0 & 0 & 0 & 0 & 0 \\
\hline & Min. / Max. & $-1.8 / 2.5$ & $-1.8 / 2.5$ & $-1.8 / 2.5$ & $-1.9 / 2.5$ & $-1.7 / 2.4$ & $-1.6 / 2.4$ & $-1.6 / 2.4$ & $-1.8 / 2.3$ \\
\hline \multirow[t]{6}{*}{$\mathrm{CPI}$} & Number of cases & 102 & 146 & 163 & 180 & 178 & 176 & 175 & 168 \\
\hline & Mean (value) & 4.558 & 4.164 & 4.091 & 4.022 & 4.008 & 43.267 & 43.189 & 42.571 \\
\hline & Mean ( $\%$ change) & - & -8.6 & -1.8 & -1.7 & -0.4 & - & -0.2 & -1.4 \\
\hline & Std. dev. (value) & 2.361 & 2.218 & 2.146 & 2.101 & 2.080 & 19.618 & 19.714 & 20.043 \\
\hline & Std. dev. (\% change) & - & -6.1 & -3.3 & -2.1 & -1.0 & - & 0.5 & 1.7 \\
\hline & Min. / Max. & $1.2 / 9.7$ & $1.5 / 9.7$ & $1.8 / 9.6$ & $1.0 / 9.3$ & $1.1 / 9.3$ & $8 / 90$ & $8 / 92$ & $8 / 91$ \\
\hline \multirow[t]{6}{*}{ EGDI } & Number of cases & 191 & 191 & 191 & 192 & 192 & 193 & 193 & 193 \\
\hline & Mean (value) & 0.364 & 0.385 & 0.400 & 0.428 & 0.420 & 0.488 & 0.471 & 0.492 \\
\hline & Mean ( $\%$ change) & - & 5.8 & 3.9 & 7.0 & -1.9 & 16.2 & -3.5 & 4.5 \\
\hline & Std. dev. (value) & 0.216 & 0.220 & 0.223 & 0.207 & 0.194 & 0.211 & 0.217 & 0.215 \\
\hline & Std. dev. (\% change) & - & 1.9 & 1.4 & -7.2 & -6.3 & 8.8 & 2.8 & -0.9 \\
\hline & Min. / Max. & $0 / 0.9$ & $0 / 0.9$ & $0 / 0.9$ & $0 / 0.9$ & $0 / 0.9$ & $0 / 0.9$ & $0 / 1$ & $0 / 0.9$ \\
\hline \multirow[t]{6}{*}{ IDI } & Number of cases & 154 & 181 & 154 & 159 & 152 & 167 & 166 & 175 \\
\hline & Mean (value) & 2.477 & 0.402 & 3.399 & 3.553 & 4.076 & 4.373 & 4.772 & 4.943 \\
\hline & Mean ( $\%$ change) & - & - & - & 4.5 & 14.7 & 7.3 & 9.1 & 3.5 \\
\hline & Std. dev. (value) & 1.442 & 0.191 & 1.904 & 1.936 & 2.094 & 2.170 & 2.209 & 2.215 \\
\hline & Std. dev. (\% change) & - & - & - & 1.7 & 8.2 & 3.6 & 1.8 & 0.3 \\
\hline & Min. / Max. & $0.5 / 6.1$ & $0 / 0.8$ & $0.8 / 7.5$ & $0.8 / 7.8$ & $0.8 / 8.4$ & $1 / 8.6$ & $1 / 8.9$ & $1.1 / 8.8$ \\
\hline \multirow[t]{6}{*}{ NRI } & Number of cases & 82 & 102 & 122 & 127 & 133 & 142 & 148 & 139 \\
\hline & Mean (value) & 3.963 & 3.590 & 3.848 & 3.930 & 3.870 & 3.957 & 4.011 & 4.142 \\
\hline & Mean (\% change) & - & -9.4 & 7.2 & 2.1 & -1.5 & 2.3 & 1.4 & 3.3 \\
\hline & Std. dev. (value) & 0.978 & 0.837 & 0.904 & 0.838 & 0.786 & 0.885 & 0.907 & 0.922 \\
\hline & Std. dev. (\% change) & - & -14.4 & 8.0 & -7.3 & -6.2 & 12.6 & 2.5 & 1.7 \\
\hline & Min. / Max. & $2.1 / 5.9$ & $2.1 / 5.5$ & $2.2 / 5.7$ & $2.4 / 5.8$ & $2.6 / 5.7$ & $2.3 / 5.9$ & $2.2 / 6.0$ & $2.2 / 6.0$ \\
\hline
\end{tabular}

Source: Authors' compilation based on the data of World Bank, Transparency International, UN, ITU and WEF. 
Figure 1 The progress of correlations coefficients among the indices through the years

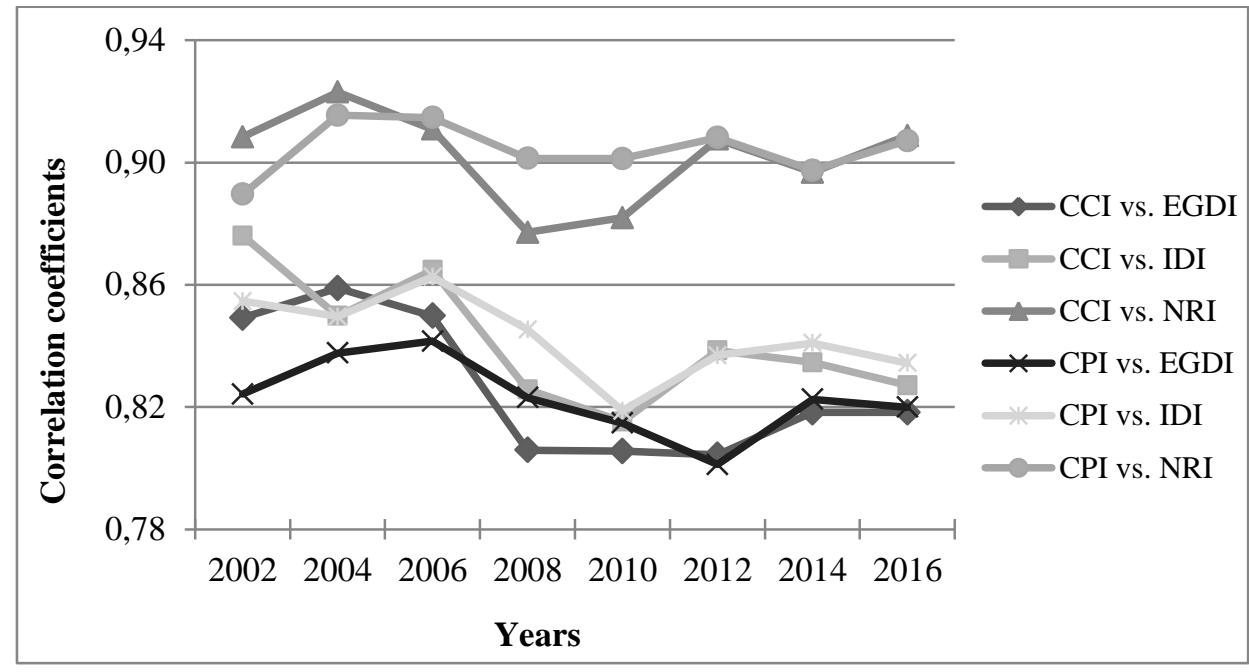

Source: Authors' own calculations.

Moreover, a decline between 2008 and 2010 has been identified where the strength of this relationship had decreased. It probably is due to the financial crisis that started at the end of 2007 and led to the global recession that affected the economies of countries around the world. As reported by Ivlevs and Hinks (2015), households hit by a crisis are more likely to bribe and, as for individuals, crisis victims tend to bribe a wider range of public officials than non-victims. Crisis victims are also more likely to pay bribes not out of gratitude but because public officials ask them to do so. Furthermore, one of the key causes of a financial crisis is a loose monetary policy (cheap money policy), which, combined with the political focus on economic growth (the growth of public debt) stimulation, may accelerate the extent of corruption perception in the economy.

Máchová and Lněnička (2016b) evaluated the influence of selected indicators on egovernment development to uncover similarities and identify areas affected by the crisis and in need of an improvement. They have learnt that the variables in the ICT infrastructure and broadband quality dimension were not affected by the global recession. Therefore, the IDI did not report any significant decline within the examined period. This claim is supported by the results in Table 2, where a percentage change of the IDI mean value increases constantly with time. It may hence be concluded that in the presence of a crisis the perception of corruption worsens faster than the level of egovernment development.

Table 3 with Spearman rank order correlations confirms these results. All of the correlations are statistically significant at the level of 0.05 . The indices measuring the level of corruption have ranked the countries closer to each other, while the indices of egovernment development are slightly different. These results have also been confirmed by Kendall tau correlations and showed that the CPI ranks countries similarly to egovernment development indices as opposed to the CCI. Hence, the CPI was used in the following regression models as the only measure for corruption. 
Table 3 Spearman rank order correlations

\begin{tabular}{|c|c|c|c|c|c|c|c|c|}
\hline \multirow{2}{*}{$\begin{array}{l}\text { Year/ } \\
\text { index }\end{array}$} & \multicolumn{2}{|c|}{2002} & \multicolumn{2}{|c|}{2004} & \multicolumn{2}{|c|}{2006} & \multicolumn{2}{|c|}{2008} \\
\hline & $\mathrm{CCl}$ & CPI & $\mathrm{CCl}$ & CPI & $\mathrm{CCl}$ & CPI & $\mathrm{CCl}$ & CPI \\
\hline EGDI & 0.636 & 0.789 & 0.661 & 0.751 & 0.688 & 0.770 & 0.691 & 0.758 \\
\hline IDI & 0.699 & 0.806 & 0.802 & 0.826 & 0.752 & 0.800 & 0.723 & 0.751 \\
\hline $\mathrm{NRI}$ & 0.900 & 0.881 & 0.912 & 0.913 & 0.861 & 0.897 & 0.841 & 0.873 \\
\hline \multirow{2}{*}{$\begin{array}{l}\text { Year / } \\
\text { index }\end{array}$} & \multicolumn{2}{|c|}{2010} & \multicolumn{2}{|c|}{2012} & \multicolumn{2}{|c|}{2014} & \multicolumn{2}{|c|}{2016} \\
\hline & $\mathrm{CCl}$ & CPI & $\mathrm{CCl}$ & CPI & $\mathrm{CCl}$ & CPI & $\mathrm{CCl}$ & CPI \\
\hline EGDI & 0.669 & 0.741 & 0.734 & 0.740 & 0.724 & 0.741 & 0.690 & 0.759 \\
\hline IDI & 0.735 & 0.765 & 0.765 & 0.752 & 0.772 & 0.763 & 0.751 & 0.771 \\
\hline NRI & 0.831 & 0.882 & 0.834 & 0.839 & 0.827 & 0.819 & 0.823 & 0.833 \\
\hline
\end{tabular}

Source: Authors' own calculations.

The results for the composite indices are in agreement with those obtained by Grönlund and Flygare (2011). They stated that while the level of corruption is very consistently measured by the CCI and CPI between the years 2003 and 2008, e-government development indices as predictors vary widely. According to their results, the Economist Intelligence Unit's (EIU) e-government index and IDI are the best predictors. The EGDI scored fairly well but none of the other tested indices could serve as a predictor, for example the Waseda index. It should be noted that the EIU has last been published in 2010. For that reason, it could not be used in this research study. The Waseda index is not used because it only covered 23 countries when it was first published in 2005 (in 2016, it covered 65 countries), so it cannot be accurately compared with others as this index does not fully reflect the wide variety of countries in the world.

Furthermore, a new finding is that the NRI, which was omitted in the study by Grönlund and Flygare (2011), is a better predictor than the EGDI or IDI. It could be argued that this result occurs due to the composition of its benchmarking framework. Therefore, a major implication for practice is the importance of monitoring the new trends in ICT and incorporating them into benchmarking frameworks (Máchová and Lněnička, 2015). The indices that are most ambitious in these trends, such as the NRI, score best. Thus, the best index should contain institutional, policy, and social analysis on top of any available statistics on factors pertaining to these trends.

The next step of this paper was to explore how far the dimensions can explain the changes of the level of the dependent variable (corruption). Table 4 displays the Pearson's correlation coefficients between each of the e-government development indices and their dimensions and corruption indices calculated using values from the examined years. As the table indicates, there is a wide variety in correlation ranging from a moderate 0.60 to a very strong 0.92 . The statistical findings of the study thus indicate that the various dimensions have different implications in the context of decreasing the corruption level. 
Table 4 The correlation matrix for the dimensions of e-government development indices

\begin{tabular}{|c|c|c|c|c|c|c|c|c|c|c|c|}
\hline \multirow{2}{*}{\multicolumn{2}{|c|}{$\begin{array}{l}\text { Year Inde } \\
\text { Dimensions }\end{array}$}} & \multicolumn{3}{|c|}{ EGDI } & \multicolumn{3}{|c|}{$I D I$} & \multicolumn{4}{|c|}{$N R I$} \\
\hline & & $\mathrm{HCl}$ & OSI & TII & Acc. & Skills & Use & Env. & Read. & Usage & Imp. \\
\hline \multirow{2}{*}{2002} & $\mathrm{CCl}$ & 0.627 & 0.619 & 0.903 & 0.889 & 0.649 & 0.837 & 0.910 & 0.876 & 0.885 & $\mathrm{~N} / \mathrm{A}$ \\
\hline & CPI & 0.619 & 0.582 & 0.887 & 0.865 & 0.619 & 0.833 & 0.896 & 0.862 & 0.859 & $\mathrm{~N} / \mathrm{A}$ \\
\hline \multirow{2}{*}{2004} & $\mathrm{CCl}$ & 0.641 & 0.699 & 0.903 & $\mathrm{~N} / \mathrm{A}$ & $\mathrm{N} / \mathrm{A}$ & $\mathrm{N} / \mathrm{A}$ & 0.922 & 0.901 & 0.893 & $\mathrm{~N} / \mathrm{A}$ \\
\hline & CPI & 0.627 & 0.663 & 0.897 & $\mathrm{~N} / \mathrm{A}$ & N/A & $\mathrm{N} / \mathrm{A}$ & 0.916 & 0.884 & 0.892 & $\mathrm{~N} / \mathrm{A}$ \\
\hline \multirow{2}{*}{2006} & $\mathrm{CCl}$ & 0.646 & 0.678 & 0.900 & 0.858 & 0.642 & 0.873 & 0.919 & 0.855 & 0.888 & $\mathrm{~N} / \mathrm{A}$ \\
\hline & CPI & 0.616 & 0.662 & 0.911 & 0.853 & 0.612 & 0.887 & 0.928 & 0.844 & 0.898 & $\mathrm{~N} / \mathrm{A}$ \\
\hline \multirow{2}{*}{2008} & $\mathrm{CCl}$ & 0.616 & 0.618 & 0.864 & 0.827 & 0.589 & 0.834 & 0.901 & 0.808 & 0.859 & $\mathrm{~N} / \mathrm{A}$ \\
\hline & CPI & 0.618 & 0.635 & 0.885 & 0.844 & 0.601 & 0.858 & 0.921 & 0.835 & 0.884 & $\mathrm{~N} / \mathrm{A}$ \\
\hline \multirow{2}{*}{2010} & $\mathrm{CCl}$ & 0.585 & 0.614 & 0.863 & 0.821 & 0.561 & 0.825 & 0.928 & 0.750 & 0.849 & $\mathrm{~N} / \mathrm{A}$ \\
\hline & CPI & 0.579 & 0.632 & 0.869 & 0.821 & 0.559 & 0.833 & 0.940 & 0.778 & 0.868 & $\mathrm{~N} / \mathrm{A}$ \\
\hline \multirow{2}{*}{2012} & $\mathrm{CCl}$ & 0.602 & 0.706 & 0.809 & 0.826 & 0.594 & 0.853 & 0.936 & 0.774 & 0.895 & 0.870 \\
\hline & CPI & 0.603 & 0.702 & 0.805 & 0.822 & 0.599 & 0.851 & 0.937 & 0.775 & 0.893 & 0.872 \\
\hline \multirow{2}{*}{2014} & $\mathrm{CCl}$ & 0.696 & 0.652 & 0.844 & 0.813 & 0.592 & 0.860 & 0.925 & 0.749 & 0.902 & 0.849 \\
\hline & CPI & 0.705 & 0.654 & 0.847 & 0.814 & 0.603 & 0.869 & 0.927 & 0.751 & 0.900 & 0.849 \\
\hline \multirow{2}{*}{2016} & $\mathrm{CCl}$ & 0.712 & 0.629 & 0.853 & 0.820 & 0.581 & 0.844 & 0.930 & 0.772 & 0.901 & 0.885 \\
\hline & CPI & 0.735 & 0.611 & 0.860 & 0.824 & 0.600 & 0.849 & 0.930 & 0.774 & 0.896 & 0.882 \\
\hline \multirow{2}{*}{$\begin{array}{l}\text { Mean } \\
\text { value }\end{array}$} & $\mathrm{CCl}$ & 0.641 & 0.652 & 0.867 & 0.836 & 0.601 & 0.847 & 0.921 & 0.811 & 0.884 & 0.868 \\
\hline & CPI & 0.638 & 0.643 & 0.870 & 0.835 & 0.599 & 0.854 & 0.924 & 0.813 & 0.886 & 0.868 \\
\hline
\end{tabular}

Source: Authors' own calculations.

According to these results, the key e-government development dimensions for corruption prevention and the coordination of anti-corruption activities are: (1) the environment sub-index, which assesses the extent to which a country's market conditions and regulatory framework support entrepreneurship, innovation, and ICT development; (2) the usage sub-index, which assesses the level of ICT adoption by a society's main stakeholders; and (3) the telecommunication infrastructure sub-index, which measures the country's ICT infrastructure capacity.

The table illustrates that dimensions related to human capital and skills, i.e. indicators such as adult literacy rate, secondary and tertiary gross enrolment ratio or mean years of schooling, only have a moderate impact on the level of corruption. Furthermore, there is no significant improvement in these dimensions through the years. It may be concluded that both correlated factors display a similar rate of growth, except in the time of the crisis. This means that higher levels of e-government development are associated with lower levels of corruption in the examined countries.

As presented above, the CPI has a stronger relationship with all of the e-government development indices. Also, as the NRI is the best predictor of the level of corruption, this relationship has been investigated more thoroughly. The natural logarithm of GDP per capita has been used as a control variable. The regression estimate using equation (1) 
is then presented in Table 5, including the parameters of models in the examined years and the coefficient of determination $\left(\mathrm{R}^{2}\right)$, which indicates the proportion of the variance in the dependent variable that can be predicted from the independent variable. The number of cases reflects the number of countries that are benchmarked by both the CPI and NRI. This table reports OLS regressions with robust standard errors, which are in the parenthesis.

The results shown in Table 5 indicate that the coefficient estimate for the NRI in all examined years is positive and statistically significant. The overall $\mathrm{R}^{2}$ for all of these models is very high. Moreover, after checking the residual plots in order to validate the model, it is apparent that e-government development has a significant impact on the level of corruption. These models explain and predict future outcomes very well. The decline in $\mathrm{R}^{2}$ that starts showing in 2012 could be explained by the digital divide that followed the crisis, where developed countries invested more in ICT than developing countries (Aladwani, 2016; Prasad and Shivarajan, 2015). Finally, the results show that the GDP may be used together with other control variable(s), which suggests more models for a possible investigation.

Table 5 Impact of e-government development on the level of corruption

\begin{tabular}{cccccc}
$\begin{array}{c}\text { Year } \\
\text { (model) }\end{array}$ & $\begin{array}{c}\text { Number } \\
\text { of cases }\end{array}$ & $\alpha$ constant & $\beta$ for NRI & $\gamma$ for GDP & Overall model $R^{2}$ \\
\hline 2002 & 80 & $-8.368(1.732)$ & $1.559(0.250)$ & $0.781(0.272)$ & 0.817 \\
2004 & 100 & $-4.498(0,921)$ & $2.717(0.232)$ & $-0.070(0.171)$ & 0.851 \\
2006 & 120 & $-4.318(0.743)$ & $2.316(0.170)$ & $-0.007(0.130)$ & 0.840 \\
2008 & 124 & $-5.087(0.719)$ & $2.254(0.175)$ & $0.081(0.124)$ & 0.818 \\
2010 & 129 & $-5.995(0.676)$ & $2.331(0.173)$ & $0.153(0.115)$ & 0.821 \\
2012 & 138 & $-25.230(7.155)$ & $20.099(1.641)$ & $-0.871(1.240)$ & 0.771 \\
2014 & 140 & $-23.307(7.897)$ & $18.574(1.804)$ & $-0.532(1.393)$ & 0.727 \\
2016 & 129 & $-25.830(8.440)$ & $19.468(1.966)$ & $-0.869(1.549)$ & 0.755 \\
\hline
\end{tabular}

Source: Authors' own calculations.

Overall, the results of this study contribute to the literature on the relationship between e-government development and the level of corruption by exploring this it on the level of decomposed sub-indices (dimensions) to avoid possible negative effects of one aggregate value represented by the composite index. Since this research approach has never been specifically used to investigate this issue before, this paper provides important benchmark data and regression models, while offering a deeper insight into the benefits of using ICT to combat and reduce corruption.

According to UN's E-government Survey 2016, countries in all regions are increasingly utilizing ICT to deliver services and engage people in decision-making processes (United Nations, 2016). At the same time, policy makers and practitioners need accurate information about the availability and use of ICT to make appropriate decisions (International Telecommunication Union, 2016). Therefore, e-government could be an effective tool to curb corruption in the public sector - that is if a high level of country's mar- 
ket conditions and regulatory framework, ICT adoption by a society's stakeholders, and country's ICT infrastructure capacity are fundamental preconditions of the government's vision. More importantly, this study indicates that a pronounced e-government development could play a significant role in anti-corruption efforts, and if governments supports these dimensions, such efforts could then effectively lower the corruption level in the public sector. For that reason, practitioners and policy makers should make concerted efforts to enhance e-government development by focusing on the growth and maturity of these dimensions. Apart from this, the results could be considered as a guide to countries trying to manage corruption and advance e-government development, helping them decide what to focus their resources and capabilities on.

Finally, if the findings of this study were taken into account with any anti-corruption efforts, then any policy leading to the elimination of corruption and the transparency of the market environment should be a successful and cost-effective economic policy. Weakening links between economic and political power, increasing transparency of processes, and the elimination of unnecessary regulations burdening the economy would contribute to the enhancement of the country's credibility, the reduction of unwanted corrupt behaviour in the economy, and to the satisfaction of the public.

\section{Limitations and Future Research}

Although ICT provide an opportunity for public organizations to be more transparent, it has to be ensured that ICT do not build on extant bureaucratic processes, thereby reinforcing the existing inefficiencies (Srivastava et al., 2016). As stated by Ramaswamy and Selian (2009), combating corruption has to be "an evolutionary process, characterized by both top down and bottom up buy in, so that it can be accepted with minimum resistance by the bureaucracy as a whole." Also, any advances in e-government must go hand in hand with efforts to bridge the digital divide (United Nations, 2016). Closer observation proves that there still are considerable variations between different regions, and particularly between countries from different development categories (International Telecommunication Union, 2016). In this regard, the first limitation is the existence of outliers among those evaluated countries that still require more research on the relationship between e-government development and the level of corruption. For example, the success rate of the implementation of ICT projects and e-government systems in the Czech Republic is quite low, so a deeper understanding of these effects would require a comparative analysis with other, similar countries. Another way of solving this issue is to conduct a cluster analysis to determine whether the relationship is different between these groups (Máchová and Lněnička, 2016b).

The second limitation would be the fact that most of the widely used corruption indices are perception-based measures that might have weak correlations with actual experiences of corruption (Olken, 2009; Seligson, 2006). However, as these cross-national measures are based on surveys assessing first-hand experiences of corruption and their results are affected by respondents' reticence in answering questions related to their participation in corrupt activities (Escresa and Picci, 2017; Treisman, 2007; Wei, 2001), it is more suitable to use already established indices. Furthermore, proposing to use judicial statistics to develop a cross-national measure of corruption may appear ungainly. These differences could even turn out to be as significant as a negative correlation be- 
tween actual and observed corrupt transactions (Escresa and Picci, 2017). After all, where corruption is endemic, the judiciary may also be corrupt or vulnerable to threats (Van Aaken et al., 2010). In this case, more consistent results could be achieved by dividing countries into groups according to their population, income level, unemployment rate, etc., as suggested, for example, by the United Nations' report on egovernment (United Nations, 2016), or their geographic location as a geopolitical regional group of states (Lupu and Lazar, 2015).

The scope of this study is limited in terms of the data available. This unavailability required resorting to the use of secondary data, utilizing data points that were present across all of the data sources and collected in a uniform way by the secondary organizations. Another limitation of this research is the composition of aggregated indices and their indicators through the time, especially when many other country-specific factors that might affect corruption could not be easily captured in such a quantitative analysis (Grönlund and Flygare, 2011; Lindstedt and Naurin, 2010; Shim and Eom, 2009). The methodology behind the calculation of these indices can thus affect the reliability of the results. Since various factors may produce different influences every year, these changes should be taken into account when consulting the results. This could also limit the research questions.

Nevertheless, considering that these indices have been formulated by reputable and authorized organizations using several suitable statistical procedures for the assessment of their validity and reliability, relying upon these data sources has provided a costeffective way for the conduction of this study. Finally, the scope of this study is also limited in terms of the economic perspective. As a result, no other factors have been employed in the regression models - although some authors, such as Andersen (2009), Elbahnasawy (2014), Kim (2014), Krishnan et al. (2013), Prasad and Shivarajan (2015) or Shim and Eom (2009), do mention some possible ones. This impediment will be addressed in future studies.

On the basis of the findings, work on the remaining issues is continuing and will be presented in future papers. More precisely, these data will be used to explore the impact of other factors (independent variables), such as government effectiveness, political stability or press freedom, and to expand the proposed regression models and their quality. Another possible area of future research would be to investigate the effects of open government and open data on the level of corruption (Máchová, 2017; Máchová and Lněnička, 2016a). As mentioned earlier, combining transparency of information with open and big data analytics has a growing potential. It could help track service delivery and lead to gains in efficiency, and also provide governments with the necessary tools to focus on prevention rather than reaction, notably in the area of disaster risk management (Lněnička, 2014; United Nations, 2016).

Moreover, as stated by Bussell (2011), new ICT provide governments with opportunities to deliver public services to the citizens more effectively. These trends are identified in, for example, Máchová and Lněnička (2015). The role of open government and open data portals should, however, be examined more thoroughly. Further studies could also focus on the various administrative levels, e.g. the impact of e-government on corruption at more granular levels of analysis, or the ICT infrastructure in various countries. 


\section{Conclusion}

This paper empirically examined the potential effects of e-government represented by decomposed e-government development sub-indices (dimensions) on corruption reduction in the period between 2002 and 2016. It introduces new insights into the relationship between these two factors and presents these effects on more detailed levels of egovernment development represented by various dimensions in time.

As for the first research question, the empirical findings confirmed that there is a relationship between e-government development and the level of corruption on the national level. A progress in the trend of this relationship between the examined years has also been found and described. These results suggest that in time of a crisis the perception of corruption generally worsens faster than the level of e-government development. Egovernment development indices consistently predict corruption. It has been assessed that the best predictor is the NRI. Dimensions with the strongest relationship with the level of corruption are the environment sub-index, the usage sub-index and the telecommunication infrastructure sub-index of the NRI; whereas dimensions related to human capital and skills only have a moderate impact on the level of corruption.

The reason why the focus of this empirical study is unique is that previous studies have either only used single index of e-government development or only evaluated selected years. This paper offers useful insights into the progress of the relationship between egovernment development and the level of corruption. It also examines the effects of each dimension of e-government development on the level of corruption independently, which can provide deeper insights into the benefits of using ICT to combat and reduce corruption. Moreover, this paper fills an important gap in the literature on how to examine the impact of e-government development and the level of corruption in the context of various dimensions in time. In this regard, it joins the stream of research that uses theoretical models and an empirical analysis to examine the importance of ICT in reducing corruption. Finally, the importance of open government movement in the provision of new channels and tools to combat corruption is suggested as a potential area for further research.

Acknowledgements: For helpful comments and suggestions that improved the quality of this paper, we would like to thank the two anonymous referees.

Disclosure statement: No potential conflict of interests was reported by the authors.

\section{References}

AHMAD, N.; BROOKINS, O. T. (2007). The Impact of Corruption on Efficiency in Developing Economies. International Journal of Economic Perspectives, 1(2), 64-73.

ALADWANI, A. M. (2016). Corruption as a source of e-Government projects failure in developing countries: A theoretical exposition. International Journal of Information Management, 36(1), 105-112. http://doi.org/10.1016/j.ijinfomgt.2015.10.005

ANDERSEN, T. B. (2009). E-Government as an anti-corruption strategy. Information Economics and Policy, 21(3), 201-210. http://doi.org/10.1016/j.infoecopol.2008.11.003 
ANDERSEN, T. B.; RAND, J. (2006). Does E-Government Reduce Corruption?. Department of Economics, University of Copenhagen's Working Paper. http://unpan1.un.org/intradoc/groups/public/documents/apcity/unpan047000.pdf. Accessed 4 October 2017.

ARMANTIER, O.; BOLY A. (2011). A controlled field Experiment on Corruption. European Economic Review, 55(8), 1072-1082. http://doi.org/10.1016/j.euroecorev.2011.04.007

ATTARD, J.; ORLANDI, F.; SCERRI, S.; AUER, S. (2015). A systematic review of open government data initiatives. Government Information Quarterly, 32(4), 399-418. http://doi.org/10.1016/j.giq.2015.07.006

BARDHAN, P. (1997). Corruption and Development: A Review of Issues. Journal of Economic Literature, 35(3), 1320-1346.

BERTOT, J. C.; JAEGER, P. T.; GRIMES, J. M. (2010). Using ICTs to create a culture of transparency: E-government and social media as openness and anti-corruption tools for societies. Government Information Quarterly, 27(3), 264-271. http://doi.org/10.1016/j.giq.2010.03.001

BERTOT, J. C.; JAEGER, P. T.; GRIMES, J. M. (2012). Promoting transparency and accountability through ICTs, social media, and collaborative e-government. Transforming Government: People, Process and Policy, 6(1), 78-91. http://doi.org/10.1108/17506161211214831

BRUNETTI, A.; KISUNKO, G.; WEDER, B. (1998). Credibility of rules and economic growth: Evidence from a worldwide survey of the private sector. The World Bank Economic Review, 12(3), 353-384.

BUSSELL, J. (2011). Explaining Cross-National Variation in Government Adoption of New Technologies. International Studies Quarterly, 55(1), 267-280. http://doi.org/10.1111/j.1468-2478.2010.00644.x

CHRISTOU, G.; SIMPSON, S. (2009). New Governance, the Internet, and Country Code Top-Level Domains in Europe. Governance, 22(4), 599-624. http://doi.org/10.1111/j.1468-0491.2009.01455.x

ELBAHNASAWY, N. G. (2014). E-Government, Internet Adoption, and Corruption: An Empirical Investigation. World Development, 57, 114-126. http://doi.org/10.1016/j.worlddev.2013.12.005

ESCRESA, L.; PICCI, L. (2017). A New Cross-National Measure of Corruption. The World Bank Economic Review, 31(1), 196-219. http://doi.org/10.1093/wber/lhv031

EVANS, A. M.; CAMPOS, A. (2013). Open Government Initiatives: Challenges of Citizen Participation. Journal of Policy Analysis and Management, 32(1), 172-185. http://doi.org/10.1002/pam.21651

GRÖNLUND, Å.; FLYGARE, A. M. (2011). The Effect of eGovernment on Corruption: Measuring Robustness of Indexes. In Andersen, K. N, et al. (Eds), Electronic Government and the Information Systems Perspective (pp. 235-248). Berlin Heidelberg: Springer. http://doi.org/10.1007/978-3-642-22961-9_19 
GYIMAH-BREMPONG, K. (2002). Corruption, economic growth, and income inequality in Africa. Economics of Governance, 3(3), 183-209. http://doi.org/10.1007/s101010200045

HOPPER, T.; TSAMENYI, M.; UDDIN, S.; WICKRAMASINGHE, D. (2009). Management accounting in less developed countries: what is known and needs knowing. Accounting, Auditing \& Accountability Journal, 22(3), 469-514. http://doi.org/10.1108/09513570910945697

INTERNATIONAL TELECOMMUNICATION UNION. (2016). Measuring the Information Society Report 2016. Geneva: Telecommunication Development Bureau.

IVLEVS, A.; HINKS, T. (2015). Global economic crisis and corruption. Public Choice, 162(3-4), 425-445. http://doi.org/10.1007/s11127-014-0213-z

JAIN, A. K. (2001). Corruption: A Review. Journal of Economic Surveys, 15(1), 71121. http://doi.org/10.1111/1467-6419.00133

KIM, C. K. (2007). A Cross-national Analysis of Global E-government. Public Organization Review, 7(4), 317-329. http://doi.org/10.1007/s11115-007-0040-5

KIM, C. K. (2014). Anti-Corruption Initiatives and E-Government: A Cross-National Study. Public Organization Review, 14(3), 385-396. http://doi.org/10.1007/s11115013-0223-1

KIM, S.; KIM, H. J.; LEE, H. (2009). An institutional analysis of an e-government system for anti-corruption: The case of OPEN. Government Information Quarterly, 26(1), 42-50. http://doi.org/10.1016/j.giq.2008.09.002

KNACK, S.; KEEFER, P. (1995). Institutions and economic performance: crosscountry tests using alternative institutional measures. Economics \& Politics, 7(3), 207227. http://doi.org/10.1111/j.1468-0343.1995.tb00111.x

KNĚZÁČKOVÁ, R.; LINHARTOVÁ, V. (2013). Impact of e-government at the level of corruption. In The 7th International Days of Statistics and Economics (pp. 621-630). Slaný: Melandrium.

KRISHNAN, S.; TEO, T. S. H.; LIM, V. K. G. (2013). Examining the relationships among e-government maturity, corruption, economic prosperity and environmental degradation: A cross-country analysis. Information \& Management, 50(8), 638-649. http://doi.org/10.1016/j.im.2013.07.003

LEITE, C. A.; WEIDMANN, J. (1999). Does Mother Nature Corrupt? Natural Resources, Corruption, and Economic Growth. IMF Working Paper No. 99/85. http://ssrn.com/abstract=259928. Accessed 4 October 2017.

LINDSTEDT, C.; NAURIN, D. (2010). Transparency is not Enough: Making Transparency Effective in Reducing Corruption. International Political Science Review, 31(3), 301-322. http://doi.org/10.1177/0192512110377602

LINHARTOVÁ, V. (2017). The role of e-government in mitigating corruption. Scientific Papers of the University of Pardubice - Series D, Faculty of Economics and Administration, 40, 120-131. 
LNĚNIČKA, M. (2014). Deployment of Big Data Analytics Approaches in the Public Administration and Comparison of IT Performance Indicators. In Špalková, D., Matějová, L. (Eds), Proceedings of the 18th International Conference Current Trends in Public Sector Research (pp. 162-169). Brno: Masaryk University.

LUPU, D.; LAZAR, C. G. (2015). Influence of e-government on the level of corruption in some EU and non-EU States. Procedia Economics and Finance, 20, 365-371. http://doi.org/10.1016/S2212-5671(15)00085-4

MÁCHOVÁ, R. (2017). Measuring the Effects of Open Data on the Level of Corruption. In Špalková, D., Matějová, L. (Eds), Proceedings of the 21th International Conference Current Trends in Public Sector Research (pp. 58-66). Brno: Masaryk University.

MÁCHOVÁ, R.; LNĚNIČKA, M. (2015). Reframing E-Government Development Indices with Respect to New Trends in ICT. Review of Economic Perspectives, 15(4), 383-411. http://doi.org/10.1515/revecp-2015-0027

MÁCHOVÁ, R.; LNĚNIČKA, M. (2016a). Exploring the Emerging Impacts of Open Data in the Public Sector. In Špalková, D., Matějová, L. (Eds), Proceedings of the 20th International Conference Current Trends in Public Sector Research (pp. 36-44). Brno: Masaryk University.

MÁCHOVÁ, R.; LNĚNIČKA, M. (2016b). Modelling E-Government Development through the Years Using Cluster Analysis. eJournal of eDemocracy and Open Government (JeDEM), 8(1), 62-83.

MÁCHOVÁ, R.; LNĚNIČKA, M. (2017). Evaluating the Quality of Open Data Portals on the National Level. Journal of Theoretical and Applied Electronic Commerce Research, 12(1), 21-41. http://doi.org/10.4067/S0718-18762017000100003

MAURO, P. (1995). Corruption and Growth. The Quarterly Journal of Economics, 110(3), 681-712. http://doi.org/10.2307/2946696

MAURO, P. (1997). The Effects of Corruption on Growth, Investment, and Government Expenditure: A Cross-Country Analysis. In K. A. Elliot (Ed.), Corruption and the global economy (pp. 83-107). Washington D.C.: Institute for International Economics.

MISTRY, J. J.; JALAL, A. (2012). An Empirical Analysis of the Relationship between E-government and Corruption. The International Journal of Digital Accounting Research, 12, 145-176. http://doi.org/10.4192/1577-8517-v12_6

MO, P. H. (2001). Corruption and Economic Growth. Journal of Comparative Economics, 29(1), 66-79. http://doi.org/10.1006/jcec.2000.1703

NARDO, M., et al. (2008). Handbook on Constructing Composite Indicators: Methodology and user Guide. Paris: OECD Publishing.

OJHA, A.; PALVIA, S.; GUPTA, M. P. (2008). A Model for Impact of E-Government on Corruption: Exploring Theoretical Foundations. In J. Bhattacharya (Ed.), Critical Thinking in E-Governance (pp. 160-170). New Delhi: Gift Publishing.

OLKEN, B. A. (2009). Corruption perceptions vs. corruption reality. Journal of Public Economics, 93(7-8), 950-964. http://doi.org/10.1016/j.jpubeco.2009.03.001 
PÉREZ, C. C.; HERNÁNDEZ, A. M. L.; BOLÍVAR, M. P. R. (2005). Citizens’ access to on-line governmental financial information: Practices in the European Union countries. Government Information Quarterly, 22(2), 258-276. http://doi.org/10.1016/j.giq.2005.02.002

PRASAD, A.; SHIVARAJAN, S. (2015). Understanding the role of technology in reducing corruption: a transaction cost approach. Journal of Public Affairs, 15(1), 22-39. http://doi.org/10.1002/pa.1484

RAMASWAMY, M.; SELIAN, A. N. (2009). The Role of E-Government in Combating Corruption in Transition Countries. Issues in Information Systems, 10(2), 66-75.

SELIGSON, M. (2006). The Measurement and Impact of Corruption Victimization: Survey Evidence from Latin America. World Development, 34(2), 381-404. http://doi.org/10.1016/j.worlddev.2005.03.012

SIAU, K.; LONG, Y. (2006). Using Social Development Lenses to Understand EGovernment Development. Journal of Global Information Management, 14(1), 47-62. http://doi.org/10.4018/jgim.2006010103

SHAHKOOH, K. A.; FASANGHARI, M.; ABDOLLAHI, A. (2008). Clustering the Countries According to Relation Between E-Government and Transparency. In 3rd International Conference on Information and Communication Technologies: From Theory to Applications (ICTTA 2008) (pp. 1-5). IEEE. http://doi.org/10.1109/ICTTA.2008.4529952

SHIM, D. C.; EOM, T. H. (2008). E-government and Anti-Corruption: Empirical Analysis of International Data. International Journal of Public Administration, 31(3), 298316. http://doi.org/10.1080/01900690701590553

SHIM, D. C.; EOM, T. H. (2009). Anticorruption effects of information communication and technology (ICT) and social capital. International Review of Administrative Sciences, 75(1), 99-116. http://doi.org/10.1177/0020852308099508

SRIVASTAVA, S. C.; TEO, T. S. H.; DEVARAJ, S. (2016). You can't bribe a computer: dealing with the societal challenge of corruption through ICT. MIS Quarterly, 40(2), $511-526$.

TANZI, V.; DAVOODI, H. (2001). Corruption, growth, and public finances. In A. K. Jain (Ed.), The Political Economy of Corruption (pp. 89-110). London: Routledge.

TRANSPARENCY INTERNATIONAL. (2016). Corruption Perceptions Index 2015. Berlin: Transparency International.

TREISMAN, D. (2007). What Have We Learned About the Causes of Corruption From Ten Years of Cross-National Empirical Research?. Annual Review of Political Science, 10, 211-244. http://doi.org/10.1146/annurev.polisci.10.081205.095418

UNITED NATIONS. (2016). United Nations e-Government Survey 2016: EGovernment in Support of Sustainable Development. New York: UN Publishing Section. 
VAN AAKEN, A.; FELD, L.; VOIGT, S. (2010). Do Independent Prosecutors Deter Political Corruption? An Empirical Evaluation across Seventy-Eight Countries. American Law and Economics Review, 12(1), 204-244. http://doi.org/10.1093/aler/ahq002

WEI, S. J. (2001). Corruption in Economic Transition and Development: Grease or Sand?. UNECE Spring Seminar. http://karmayog.org/anticorruption/upload/914/Wei.pdf. Accessed 4 October 2017.

WEST, D. M. (2004). E-Government and the Transformation of Service Delivery and Citizen Attitudes. Public Administration Review, 64(1), 15-27. http://doi.org/10.1111/j.1540-6210.2004.00343.x

WHITE, H. (1980). A Heteroskedasticity-Consistent Covariance Matrix Estimator and a Direct Test for Heteroskedasticity. Econometrica, 48(4), 817-838. http://doi.org/10.2307/1912934

WORLD ECONOMIC FORUM. (2016). The Global Information Technology Report 2016: Innovating in the Digital Economy. Geneva: SRO-Kundig. 